\title{
KADAR LAKTOSA, GULA REDUKSI, DAN NILAI pH YOGHURT DENGAN PENAMBAHAN BEKATUL SELAMA 15 HARI PENYIMPANAN REFRIGERASI
}

\author{
Lactose Content, Reducing Sugar, and pH Value of Yoghurt by Addition of Rice \\ Bran for 15 Days Refrigeration Storage
}

\author{
Dyah Laksito Rukmi' ${ }^{1}$, Rizza Wijaya ${ }^{2}$, dan Rizki Amalia Nurfitriani ${ }^{1}$ \\ 1 Jurusan Peternakan, Politeknik Negeri Jember \\ 2Jurusan Teknologi Pertanian, Politeknik Negeri Jember \\ Email: rizza.wijaya@polije.ac.id
}

\begin{abstract}
INTISARI
Penelitian ini bertujuan untuk mengetahui pengaruh lama simpan refrigerasi selama 15 hari terhadap kadar laktosa, gula reduksi, dan nilai pH yoghurt dengan penambahan bekatul. Rancangan percobaan yang digunakan dalam penelitian ini adalah rancangan acak lengkap (RAL) dengan 4 perlakuan dan 5 ulangan. Perlakuan dalam penelitian ini terdiri dari T0 (tanpa penyimpanan), T1 (5 hari penyimpanan), T2 (10 hari penyimpanan), dan T3 (15 hari penyimpanan). Data hasil uji kadar laktosa, gula reduksi, dan nilai $\mathrm{pH}$ yoghurt dianalisis dengan analisis variansi pola searah. Apabila terdapat perbedaan yang nyata diuji lanjut dengan uji Duncan's Multiple Range Test. Yoghurt dengan penambahan bekatul yang disimpan selama 15 hari di refrigerator dapat menurunkan kadar laktosa dan nilai $\mathrm{pH}$ serta meningkatkan kadar gula pereduksi yoghurt, sehingga dapat menjaga kualitas dan kesegaran yoghurt.
\end{abstract}

Kata kunci: Bekatul, Gula Reduksi, Kadar Laktosa, Nilai pH, Yoghurt

\section{ABSTRACT}

This study aimed to determine the effect of 15 days refrigeration storage on lactose content, reducing sugars, and the $\mathrm{pH}$ value of yoghurt by addition of rice bran. The experimental design used a completely randomized design (CRD) for 4 treatments and 5 replications. The treatments consisted of T0 (without storage), T1 (5 storage days), T2 (10 storage days), and T3 (15 storage days). The results showed that lactose content, reducing sugar, and $p H$ value of yoghurt were analyzed by analysis of variance (ANOVA). If there were significant differences, then further tested by Duncan's Multiple Range Test. Yoghurt by addition of rice bran stored for 15 days in the refrigerator could reduce lactose content and $\mathrm{pH}$ values and increased the level of reducing sugar, so that be able to maintain the quality and freshness of yoghurt.

Keywords: Rice bran, Reducing Sugar, Lactose Content, pH Value, Yoghurt

\section{PENDAHULUAN}

Susu merupakan bahan pangan yang tersusun oleh zat-zat makanan dengan proporsi seimbang, namun bersifat perishable atau mudah rusak. Kerusakan susu disebabkan oleh beberapa faktor yaitu faktor kimiawi, fisik, dan mikrobiologi (Hariono et al., 2020). Faktor mikrobiologi adalah faktor utama penyebab kerusakan susu. Kerusakan pada susu tersebut dapat diminimalkan melalui penerapan teknologi pengolahan susu, salah satunya adalah yoghurt. Yoghurt dihasilkan melalui proses fermentasi susu oleh bakteri dengan mengubah gula susu (laktosa) menjadi asam laktat (Ide, 2008). Substansi yang dihasilkan oleh bakteri asam laktat (BAL) dan komponen mikrobia memberikan karakteristik asam dan aroma yoghurt (Widodo, 2003).

Hasil metabolisme laktosa berupa asamasam organik akan mempengaruhi cita rasa dan ikut menentukan kualitas yoghurt. Hui (1993) menyatakan bahwa flavor yoghurt yang 
khas diperoleh dengan pembentukan asam laktat, asetaldehid, asam asetat, dan diasetil. Yoghurt merupakan pangan fungsional yang bermanfaat bagi kesehatan saluran pencernaan manusia. Peranan positif yoghurt bagi kesehatan terutama didukung adanya probiotik yang dapat membantu mikrobia usus. Yoghurt sebagai produk susu fermentasi bergizi tinggi, namun tidak mengandung serat. Oleh karena itu, perlu adanya penambahan bahan sumber serat. Bahan sumber serat yang dapat digunakan adalah bekatul (rice bran).

Bekatul merupakan hasil samping penggilingan padi yang diperoleh dari lapisan luar karyopsis beras. Bekatul komersial mengandung sejumlah pati yang kadarnya berkisar antara 10 sampai 55\% dengan kadar total gula antara 3 sampai 5\% (bahan kering). Glukosa, fruktosa, sukrosa, dan rafinosa terkandung dalam bekatul. Jenis-jenis gula tersebut dibutuhkan oleh BAL untuk bertahan hidup sehingga berkaitan erat dengan daya simpan yoghurt. Serat pangan yang umumnya ditambahkan dalam produk susu fermentasi dapat meningkatkan fungsional dari produk pangan tersebut dan fungsi serat pangan lainnya yaitu mudah larut dalam air dan mempunyai sifat mengikat air (Damayanthi et al., 2007).

Yoghurt merupakan produk pangan yang memiliki masa simpan tertentu dan akan mengalami penurunan kualitas selama proses penyimpanan (Ihsan et al., 2017). Penyimpanan adalah salah satu tahapan pasca panen yang berpotensi untuk mencegah terjadinya kerusakan bahan pangan. Waktu dalam proses penyimpanan merupakan faktor yang sangat penting dalam menentukan tingkat kerusakan bahan pangan (Haryadi, 2010). Salah satu cara penyimpanan yoghurt yang banyak digunakan yaitu refrigerasi, tetapi belum diketahui secara pasti waktu yang optimal untuk lama simpan yoghurt. Tujuan dari penelitian ini adalah untuk mengetahui pengaruh lama simpan refrigerasi selama 15 hari terhadap kadar laktosa, gula reduksi, dan nilai $\mathrm{pH}$ yoghurt dengan penambahan bekatul.

\section{MATERI DAN METODE}

\section{Materi Penelitian}

Alat penelitian yang digunakan meliputi mikropipet, tabung reaksi, sentrifus, kuvet, vortex, spektrofotometer, inkubator, $\mathrm{pH}$ meter, dan erlenmeyer. Bahan yang digunakan dalam penelitian ini adalah susu segar, bekatul, kultur starter (Lactobacillus acidophilus FNCC 0051, Streptococcus thermophillus FNCC 0040, dan Bifidobacterium bifidum) yang diperoleh dari Pusat Studi Pangan dan Gizi Universitas Gadjah Mada, Yogyakarta, dan reagen untuk uji kadar laktosa dan gula reduksi.

\section{Metode Penelitian}

\section{Penumbuhan starter dalam media MRS broth}

MRS broth sebanyak 5,2 g dalam $100 \mathrm{ml}$ aquades disterilisasi menggunakan autoklaf pada suhu $121^{\circ} \mathrm{C}$ selama 15 menit. MRS broth didinginkan sampai suhu $40^{\circ} \mathrm{C}$. Kultur starter ditambahkan, kemudian diinkubasi pada suhu $39^{\circ} \mathrm{C}$ selama 48 jam (Widowati dan Misgiyarta, 2002).

\section{Pembuatan mother starter}

Masing-masing starter (Lactobacillus acidophilus FNCC 0051, Streptococcus thermophillus FNCC 0040, dan Bifidobacterium bifidum) diinokulasikan pada susu UHT dengan dosis masing-masing sekitar $10^{5}$ sampai $10^{7}$ $\mathrm{CFU} / \mathrm{ml}$, kemudian diinkubasi pada suhu $39^{\circ} \mathrm{C}$ selama 8 jam (Modifikasi Widowati dan Misgiyarta, 2002).

\section{Pembuatan bulk starter}

Masing-masing starter (LA: ST: BB) diinokulasikan pada susu UHT dengan perbandingan (1:1:1) hingga mencapai kepadatan bakteri $10^{5}$ sampai $10^{7} \mathrm{CFU} / \mathrm{ml}$, lalu diinkubasi pada suhu $39^{\circ} \mathrm{C}$ selama 8 jam.

\section{Proses pembuatan yoghurt}

Susu UHT ditambahkan bekatul sebanyak $2 \%$ (b/v), dipasteurisasi pada suhu $72^{\circ} \mathrm{C}$ selama 15 detik, kemudian suhu diturunkan sampai $39^{\circ} \mathrm{C}$. Bulk starter 
diinokulasikan sebanyak $5 \% \quad(\mathrm{v} / \mathrm{v})$ dan diinkubasi pada suhu $39^{\circ} \mathrm{C}$ selama 8 jam hingga mencapai keasaman $\mathrm{pH} 4$ sampai 5. Yoghurt disimpan dalam refrigerator sesuai perlakuan yaitu T0 (tanpa penyimpanan), T1 (5 hari), T2 (10 hari), dan T3 (15 hari), kemudian masingmasing yoghurt sesuai perlakuan diuji kandungan kimia seperti kadar laktosa, gula reduksi, dan nilai $\mathrm{pH}$.

\section{Pengujian kadar laktosa}

Metode pengujian kadar laktosa (AOAC, 2005). Sampel yoghurt dimasukkan ke dalam tabung reaksi tertutup dan ditambahkan reagen $\mathrm{ZnSO}_{4} \quad(5 \%)$ dan $\mathrm{Ba}(\mathrm{OH})_{2} \quad(4,5 \%)$ masing-masing $0,2 \mathrm{ml}$ kemudian disentrifus pada kecepatan $1.000 \mathrm{ppm}$ selama 5 menit hingga terbentuk endapan. Selanjutnya $1 \mathrm{ml}$ supernatan dimasukkan ke dalam tabung reaksi tertutup, lalu ditambahkan 2,5 ml reagen Telles.

Tabung direndam dalam air mendidih selama 6 menit hingga volume $12,5 \mathrm{ml}$, kemudian ditambah terus sampai homogen. Selanjutnya absorbansi dibaca pada panjang gelombang $520 \mathrm{~nm}$. Nilai kadar laktosa, gula reduksi, dan nilai pH susu sebelum fermentasi seperti pada Tabel 1 .

Tabel 1. Nilai Kadar Laktosa, Gula Reduksi, dan Nilai pH Susu Sebelum Fermentasi

\begin{tabular}{lcccc}
\hline \multicolumn{1}{c}{ Perlakuan } & Susu Segar & Bekatul & Susu Bekatul & $\begin{array}{c}\text { Susu Bekatul } \\
\text { Sebelum Inkubasi }\end{array}$ \\
\hline Kadar laktosa & 1,62 & 0,77 & 3,00 & 3,77 \\
Kadar gula reduksi & 1,56 & 1,82 & 3,52 & 3,66 \\
Nilai pH & 7,00 & 6,60 & 6,50 & 6,40 \\
\hline
\end{tabular}

\section{Pengujian kadar gula reduksi}

Metode pengujian gula reduksi menurut AOAC (2005). Larutan glukosa standar (10 mg glukosa anhidrat/100 ml) dibuat terlebih dahulu. Larutan glukosa standar tersebut dilakukan 6 kali pengenceran hingga didapat larutan glukosa dengan konsentrasi 2, 4, 6, 8, dan $10 \mathrm{mg} / 100 \mathrm{ml}$. Tabung reaksi sebanyak 6 buah masing-masing diisi dengan $1 \mathrm{ml}$ larutan glukosa standar. Satu tabung diisi $1 \mathrm{ml}$ air suling sebagai blangko.

Masing-masing tabung reaksi ditambah $1 \mathrm{ml}$ reagensia Nelson dan dipanaskan pada penangas air mendidih selama 20 menit. Tabung semua diangkat kemudian didinginkan dalam gelas piala yang berisi air dingin hingga suhu tabung mencapai $25^{\circ} \mathrm{C}$ dan ditambahkan $1 \mathrm{ml}$ reagensia Arsenomoblydat hingga homogen. Masing-masing larutan tersebut ditera dengan optical density (OD) pada panjang gelombang $540 \mathrm{~nm}$. Kurva standar yang menunjukkan hubungan antara konsentrasi glukosa dan OD kemudian masuk ke dalam rumus $\mathrm{y}=\mathrm{a}+\mathrm{bx}$.

\section{Pengujian nilai pH}

Nilai pH yoghurt diukur dengan metode AOAC (2005). Nilai pH diukur menggunakan $\mathrm{pH}$ meter yang telah dibersihkan dan dikalibrasi. Alat $\mathrm{pH}$ meter dibersihkan dengan cara katoda indikator dicelupkan ke dalam aquades. Kalibrasi dilakukan dengan cara ujung katoda dimasukkan ke dalam buffer $\mathrm{pH} 7$ sampai pH meter menunjukkan angka 7 (konstan), kemudian katoda indikator dicelupkan kembali ke dalam aquades dan dibersihkan dengan tisu. Alat $\mathrm{pH}$ meter dikalibrasi kemudian dilakukan pengukuran $\mathrm{pH}$ terhadap sampel yoghurt sebanyak $10 \mathrm{ml}$ dengan cara mencelupkan batang $\mathrm{pH}$ meter pada sampel. Nilai $\mathrm{pH}$ yoghurt diukur sebanyak tiga kali kemudian dirata-rata.

\section{Analisis data}

Data hasil penelitian yang diperoleh yaitu uji kadar laktosa, gula reduksi, dan nilai $\mathrm{pH}$ yoghurt dianalisis dengan analisis variansi pola searah. Apabila terdapat perbedaan yang nyata diuji lanjut dengan uji Duncan's Multiple Range Test. 


\section{HASIL DAN PEMBAHASAN}

Penyimpanan merupakan salah satu faktor yang mempengaruhi stabilitas pangan. Salah satu alat yang biasa digunakan untuk menyimpan bahan pangan adalah refrigerator. Prinsip kerja refrigerator melalui mekanisme pengendalian suhu. Menurut Sari dan Hadiyanto (2013) yang menyatakan bahwa penyimpanan bahan makanan bertujuan mencegah pembusukan makanan sehingga shelf life cukup lama dan kualitasnya tetap terjaga.

Kondisi fisik, kimia, dan mikrobiologi yoghurt akan berubah seiring dengan lamanya penyimpanan. Salah satu cara yang tepat untuk dapat mempertahankan kualitas produk yoghurt adalah dengan menghambat atau mengendalikan pertumbuhan bakteri patogen, perubahan kimia, dan biokimia. Pengendalian suhu selama penyimpanan dapat mempertahankan warna, rasa, tekstur, dan zat gizi bahan pangan. Yoghurt hasil fermentasi disimpan pada suhu penyimpanan $4^{\circ} \mathrm{C}$ untuk mempertahankan cita rasa dan aroma.

\section{Kadar Laktosa}

Laktosa merupakan karbohidrat utama di dalam susu yang berfungsi sebagai sumber energi utama BAL. Kandungan laktosa di dalam produk susu sangat bervariasi tergantung cara pembuatan dan perlakuannya (Muchtadi et al., 1992). Hasil penelitian menunjukkan bahwa lama umur simpan berpengaruh sangat nyata $(\mathrm{P}<0,01)$ terhadap kadar laktosa yoghurt (Tabel 2).

Kadar laktosa yoghurt pada perlakuan T0 sebesar 2,258\% merupakan hasil yang paling tinggi dibandingkan dengan perlakuan lainnya, dan kadar laktosa paling rendah adalah pada perlakuan T3 yaitu sebesar 1,862. Hal ini menunjukkan bahwa perlakuan T3 memiliki kualitas yoghurt terbaik.

Hasil tersebut menunjukkan bahwa semakin lama proses penyimpanan yoghurt maka kemampuan bakteri untuk memecah laktosa semakin banyak, sehingga kadar laktosa dalam yoghurt semakin menurun. Menurut Kumalasari et al. (2013) bahwa seiring dengan peningkatan kemampuan BAL untuk memecah laktosa maka akan semakin menurunkan kadar laktosa dalam yoghurt yang dihasilkan.

Selama proses penyimpanan BAL akan memfermentasi laktosa menjadi glukosa dan galaktosa. Adanya aktivitas BAL menyebabkan laktosa yang ada dalam yoghurt akan mengalami penurunan dan terjadi kenaikan kadar asam laktat. Hal ini sesuai dengan pendapat Susilorini dan Sawitri (2007) yang menyatakan bahwa BAL akan mengurai laktosa yang terdapat dalam susu menjadi asam laktat.

\section{Kadar Gula Reduksi}

Kadar gula reduksi menunjukkan banyaknya gula sederhana yang telah dipecah dan digunakan oleh BAL untuk proses metabolisme. Gula reduksi meliputi laktosa, laktulosa, maltulosa, dan melibiosa. Sifat pereduksi dari molekul gula ditentukan oleh ada tidaknya gugus hidroksil ( $\mathrm{OH}-$ ) bebas yang reaktif (Winarno, 2004).

Hasil penelitian menunjukkan bahwa dengan semakin lama penyimpanan akan meningkatkan persentase gula reduksi yang terkandung dalam yoghurt. Kadar gula reduksi tertinggi terdapat pada perlakuan T3 dengan penyimpanan selama 15 hari sebesar 2,983\% (Tabel 2). Kadar gula reduksi yang semakin meningkat berasal dari gula susu yaitu laktosa dan gula sederhana yang terkandung dalam bekatul yang telah diproduksi selama proses fermentasi dan penyimpanan (Tabel 1).

Laktosa merupakan gula reduksi utama yang akan dipecah dan digunakan oleh bakteri asam laktat (BAL) untuk proses metabolisme. Besarnya penurunan kadar laktosa dalam yoghurt dan kenaikan kadar gula reduksi mengindikasikan bahwa selain memanfaatkan laktosa, BAL juga memfermentasi gula-gula sederhana lain yang terdapat dalam serat pangan bekatul (Tabel 1). 


\section{Nilai pH}

Nilai pH merupakan cerminan jumlah ion $\mathrm{H}^{+}$dari asam di dalam susu yang diakibatkan oleh pertumbuhan mikrobia. Tujuan dari pengujian nilai $\mathrm{pH}$ adalah untuk mengetahui tingkat keasaman yoghurt sehingga dapat menentukan tingkat kualitas dan keamanan yoghurt yang akan dikonsumsi (Legowo dan Kusrahayu, 2009).

Hasil penelitian menunjukkan bahwa lama penyimpanan berpengaruh sangat nyata $(\mathrm{P}<0,01)$ terhadap nilai $\mathrm{pH}$ yoghurt. Nilai $\mathrm{pH}$ produk yoghurt dengan penambahan bekatul yaitu 5,229 sampai 5,152 (Tabel 2). Perlakuan T3 dengan masa simpan 15 hari memiliki nilai pH paling rendah daripada perlakuan lainnya yaitu sebesar 5,152. Hal ini menunjukkan bahwa produk yoghurt yang disimpan dalam suhu refrigerasi tersebut masih tetap dapat mempertahakan kualitasnya ditinjau dari nilai $\mathrm{pH}$.

Nilai $\mathrm{pH}$ yang rendah disebabkan oleh adanya peningkatan keasaman yoghurt. Hal ini karena selama penyimpanan refrigerasi masih terjadi proses fermentasi yang ditunjukkan dengan peningkatan jumlah asam laktat. Zubaidah et al. (2012) menyatakan bahwa kultur starter BAL homofermentatif menghasilkan asam laktat sebagai metabolit primer. Asam laktat yang dihasilkan oleh BAL akan terekskresi keluar sel dan terakumulasi dalam media fermentasi sehingga terjadi penurunan nilai pH (Charalampopoulos et al., 2002).

Tabel 2. Rerata Kadar Laktosa, Kadar Gula Reduksi, dan Nilai pH Yoghurt

\begin{tabular}{cccc}
\hline \multirow{2}{*}{ Perlakuan } & Kadar Laktosa $(\%)$ & $\begin{array}{c}\text { Kadar Gula Pereduksi } \\
(\%)\end{array}$ & Nilai pH \\
\hline T0 & $2,258^{\mathrm{a}}$ & $2,587^{\mathrm{a}}$ & $5,229^{\mathrm{a}}$ \\
T1 & $2,016^{\mathrm{ab}}$ & $2,829^{\mathrm{ab}}$ & $5,205^{\mathrm{ab}}$ \\
T2 & $1,944^{\mathrm{bc}}$ & $2,901^{\mathrm{bc}}$ & $5,178^{\mathrm{bc}}$ \\
T3 & $1,862^{\mathrm{c}}$ & $2,983^{\mathrm{c}}$ & $5,152^{\mathrm{c}}$ \\
\hline
\end{tabular}

a,b,c Superskrip yang berbeda pada baris yang sama menunjukkan perbedaan yang sangat nyata $(\mathrm{P}<0,01)$

\section{KESIMPULAN}

Yoghurt dengan penambahan bekatul yang disimpan selama 15 hari di refrigerator dapat menurunkan kadar laktosa dan nilai $\mathrm{pH}$ serta meningkatkan kadar gula pereduksi yoghurt, sehingga dapat menjaga kualitas dan kesegaran yoghurt.

\section{DAFTAR PUSTAKA}

AOAC. 2005. Official Methods of Analysis of the Association of Official Analytical Chemist. Association of Official Analytical Chemist. Washington.

Charalampopoulos, D., R. Wang, S.S. Pandiella, and C. Webb. 2002. Application of cereals and cereal components in functional foods: a review. International Journal of Food Microbiology. 79(1-2):131-141.

Damayanthi, E., L.T. Tjing, dan L. Arbianto. 2007. Rice Bran. Penerbit Swadaya. Jakarta.
Hariono, B., R. Wijaya, and S. Anwar. 2020. Comparative study on the physical characteristics of goat milk pasteurization through serial and circulation systems of ultraviolet method. Journal of Physics: Conference Series. 1450:14-19.

Haryadi, Y. 2010. Peranan penyimpanan dalam menunjang ketahanan pangan. Pangan. 19(4):345-359.

Hui, Y.H. 1993. Dairy Science and Technology Handbook: Product Manufacturing. Volume 2. Wiley. New Jersey.

Ide, P. 2008. Health Secret of Kefir: Menguak Keajaiban Susu Asam untuk Penyembuhan Berbagai Penyakit. PT Elex Media Komputindo. Jakarta.

Ihsan, R.Z., D. Cakrawati, M.N. Handayani, dan S. Handayani. 2017. Penentuan umur simpan yoghurt sinbiotik dengan penambahan tepung gembolo modifikasi fisik. Edufortech. 2(1):1-6.

Kumalasari, K.E.D., A.M. Legowo, dan A.N.M. AlBaarri. 2013. Total bakteri asam laktat, 
kadar laktosa, pH, keasaman, kesukaan drink yogurt dengan penambahan ekstrak buah kelengkeng. Jurnal Aplikasi Teknologi Pangan. 2(4):165-168.

Legowo, A. M. dan M.S. Kusrahayu. 2009. Ilmu dan Teknologi Susu. Badan Penerbit Universitas Diponegoro. Semarang.

Muchtadi, D., N.S. palupi, dan M. Astawan. 1992. Petunjuk Laboratorium Metoda Kimia Biokimia dan Biologi dalam Evaluasi Nilai Gizi Pangan Olahan. Pusat Antar Universitas Pangan dan Gizi. Institur Pertanian Bogor. Bogor.

Sari, D.A. dan H. Hadiyanto. 2013. Teknologi dan metode penyimpanan makanan sebagai upaya memperpanjang shelf life. Jurnal Aplikasi Teknologi Pangan. 2(2):52-59.

Susilorini, T.E. dan M.E. Sawitri, 2007. Produk Olahan Susu. Penebar Swadaya. Depok.

Widodo. 2003. Bioteknologi Industri Susu. Lacticia Press. Yogyakarta.

Widowati, S. dan Misgiyarta. 2002. Efektifitas bakteri asam laktat (BAL) dalam pembuatan produk fermentasi berbasis protein/susu nabati. Prosiding Seminar Hasil Penelitian Rintisan dan Bioteknologi Tanaman. 360-373

Winarno, F.G. 2004. Kimia pangan dan Gizi. PT Gramedia Pustaka Utama. Jakarta.

Zubaidah, E., E. Saparianti, dan J. Hindrawan. 2012. Studi aktivitas antioksidan pada bekatul dan susu skim terfermentasi probiotik (Lactobacillus plantarum B2 dan Lactobacillus acidophillus). Jurnal Teknologi Pertanian. 13(2):111-118. 